\title{
Muslims of Interwar Lithuania: The Predicament of a Torn Autochthonous Ethno-Confessional Community
}

\author{
Egdūnas Račius
}

\section{Introduction}

Though various aspects of the history of the Muslim presence, which stretches for more than six hundred years, in the territory of what once was the Grand Duchy of Lithuania (GDL), have been studied rather extensively, mainly in Polish historiography but also in that of Lithuania and Belarus, one particular period seems to have escaped the attention of historians. It is the interwar period, the time of the first Lithuanian Republic between 1918 and 1940. A contemporary Polish historian Stanisław Kryczyński in his otherwise seminal study from 1938, Tatarzy litewscy. Próba monografii historyczno-etnograficznej (Lithuanian Tatars. An attempt at historic-ethnographic monograph), barely mentions the situation of Tatars in the Republic of Lithuania at the time. ${ }^{1}$ It took over fifty years for the first scholarly article on the interwar Lithuanian Tatar community to appear in Lithuanian. ${ }^{2}$ Practically all other publicly available information on that period has come in the form of memoirs of Tatars themselves published in their monthly Lietuvos totoriai (Lithuanian Tatars) over the past fifteen or so years.

The absence of interest among historians in the life of the Muslim community in interwar Lithuania can partially be explained by its numerical and consequently socio-political, let alone economic, insignificance in the general life of the Lithuanian nation in that period-Lithuanian Tatars, who made up the bulk of the Muslim community in the country, had never posed any political or social challenge to the state or society to be placed on the radar of either politicians, media, the powerful and seemingly omnipresent Catholic Church, or

1 Stanisław Kryczyński, Tatarzy litewscy. Próba monografii historyczno-etnograficznej (Warsaw, 1938).

2 Tamara Bairašauskaitė, "Musulmonų konfesinė bendruomenė nepriklausomoje Lietuvoje," Lietuvos istorijos metraštis 1991 (1993). 
local scholars and intellectuals, for that matter. ${ }^{3}$ However, the main reason for the present lack of interest in the study of the interwar Muslim community in Lithuania may actually lie in the unavailability of sources (in the form of verbal material) for research.

Therefore, like Bairašauskaitè's article of more than twenty years ago, the current text relies heavily on the same available archival material, consisting of several hundred individual documents kept in the Lithuanian State Archive. Though this material, chiefly comprising written communication between, on the one side, state institutions, and on the other side, the Tatar congregations and individual Tatars, does not provide a comprehensive picture of the (religious) life of Lithuania's Muslim Tatars in the interwar period, it nonetheless allows a glimpse into the internal structures and dynamics of relations in the community as well as the congregations' positions vis-à-vis the state and the wider society. The available material also allows one to gain an insight into how the state (in the person of relevant institutions) perceived and treated the community. Ultimately, the interwar period is a (largely missing) connecting link between the centuries-long presence of Muslim Tatars in the territory of the former Grand Duchy of Lithuania prior to the emergence of sovereign modern nation-states in that territory and the present situation. These precious few documents from the period that have been preserved deserve to be made public both to the Lithuanians who themselves know very little about the Tatar history in the country and to outside readers who because of natural obstacles like the language of the documents and their relative inaccessibility (the documents have not been digitalized and are available only on request and in person at the State Archive) have even less opportunity to familiarize themselves with this aspect of, indeed, European history.

Though, admittedly miniscule in absolute numbers, the Muslim community of interwar Lithuania is nonetheless part and parcel of the broader European and indeed global history. Along with the Polish and Byelorussian Muslim communities, the Lithuanian Tatar Muslim community during that time can be regarded as a sort of link between, on the one hand, the more established, albeit rapidly declining and increasingly weaker Muslim communities in the

3 This is, in a way, attested to by the fact that the Lithuanian print media of the interwar period ran only a handful of articles, interviews, and reports on Lithuania's Muslim community. See the digital archive of the Lithuanian print media, Lithuanian Cultural Heritage in the Virtual Environment, at http://www.epaveldas.lt/vbspi/content/about.jsp. 
Tatar ancestral lands in Eastern Europe (in the Soviet Ukraine and Russia, and Crimea in particular) and, on the other hand, western Europe, where Muslim communities were just beginning to form. The Lithuanian Tatar community shared both the memories of where they came from and a feeling of loyalty to and belonging in Lithuania.

The main aim of the chapter is to reveal the process and consequences of the identity change in the Tatar Muslim community in the territory of the interwar Lithuanian nation-state as they are captured in the formal communication between the communities and state authorities. The chapter also shows how closely the Lithuanian Muslim community's public expression of identity through rhetoric and behavior correlated with (or even depended on) the official state stance and policies toward the neighboring nation states, in this case Poland. It further illustrates how the once single Muslim community of the former Grand Duchy of Lithuania, because of certain geopolitical circumstances (like the emergence of nation states), mutated into several separate, even antagonistic, national Muslim communities, which, when given a chance, refused to re-unite. This birth of new national identities among Tatars of the former Grand Duchy of Lithuania is well worth a deeper analytical look as it contributes to a wider picture of identity changes and identity building among Muslims in interwar Europe. In this regard, the Lithuanian (and arguably Polish as well as Byelorussian) Tatar case is an alternative to the otherwise stereotypically perceived process of integration and indigenization of Muslims in Europe, then and now.

In most historiography, the Tatars of the Grand Duchy of Lithuania are referred to as 'Lithuanian Tatars,' as opposed to Crimean and Kazan Tatars. In the interwar period, however, next to this historical title, new ones appeared that reflect the political reality of the new nation-states. So, Tatars in Poland came to be called 'Polish Tatars,' while those living in the Soviet Republic of Byelorussia were called 'Byelorussian Tatars.' In this article, the designation 'Lithuanian Tatars' primarily means those Tatars who were living in the territory of the sovereign interwar Lithuanian state. Furthermore, since the overwhelming majority of Lithuania's Muslims in that period were ethnic Tatars, and virtually all Tatars were (at least nominal) Muslims, the titles 'Tatars' and 'Muslims' (and consequently 'Lithuanian Tatars' and 'Lithuanian Muslims') in this article are treated as synonyms and used interchangeably.

While interwar Lithuanian Tatars called their local religious communities 'parish' (parapija), in this article they are called 'congregations;' the term 'community' is used only when applied to Lithuanian Muslims in toto. 
The history of Islam in Lithuania dates back to the fourteenth century when the first migrants - political refugees - from the Golden Horde (and later, the Crimean Khanate) came to the Grand Duchy of Lithuania. Soon they were joined by new arrivals, consisting chiefly of mercenaries hired by Lithuanian grand dukes, more refugees, and prisoners of war who, once freed, chose to stay. The immigrants, the majority of whom were recently Islamized Turkic speakers (Tatars), eventually settled in the northwestern parts of the Duchy, mainly in village communities around the capital Vilnius. Arguably, the choice of settlement area was deliberate on the side of the Lithuanian rulers-Tatars were settled on the monarch's lands close to the seat of power, so they could be accessible and available whenever needed.

Despite or because of the fact that Muslims have been only a tiny minority of the citizenry of the Duchy (though precise data are not available, it can be safely assumed that at no time in history did the Muslim population of the GDL exceed 100,000 souls), they enjoyed almost all the rights and freedoms that their Christian fellow citizens did. Upon settlement, the Tatar elite were granted ranks of nobility and given tracts of land to be used as fiefs that later became their personal possessions. Even more, the Muslims in the Grand Duchy of Lithuania (and later, post-1569, in the Republic of Two Nations) were never forced to abandon their faith either through coerced conversion or because of artificially created obstacles in practicing their religion (such as bans, prohibitions, segregationist decrees, etc.). In the GDL/the Republic of Two Nations, Muslims throughout the centuries, with a few brief exceptions, were allowed to publicly observe practically all Islamic duties and rituals.

It is believed that mosques on the then territory of the Grand Duchy were being built as early as the late fourteenth or beginning of the fifteenth century. ${ }^{4}$ In the times of the Republic of Two Nations (that is, until the final partition in 1795) there might have been up to two dozen mosques, ${ }^{5}$ usually with adjacent cemeteries. These mosques were apparently run by local communities with little if any outside interference. The congregation as an independent body would choose its own religious leaders-mullas (formally called imams). Though the level of erudition and education of those mullas is impossible to assess (and there are indications that it has never been high, as many of them were not even capable of reading Arabic, and the first ever translation of the

4 Stanislovas Kričinskis, Lietuvos totoriai (Vilnius: Mokslo ir enciklopedijų leidykla, 1993), 158.

5 Ibid., 161. 
Qurān into Polish, the lingua franca of the time among at least the educated local Tatars, publicly appeared only in 1858), in the absence of any institutionalized religious hierarchy and formalized religious education, they appear to have been (the sole) spiritual guides for Muslims of the GDL and later the Republic of Two Nations. In general, throughout the history of Lithuanian Muslims, mullas were highly respected as, next to their spiritual and ritual functions, they were frequently among the few literate and therefore they took charge of administrative affairs within the community; sometimes they even performed the function of safekeeping the personal treasures of members of their congregations. ${ }^{6}$ Throughout the times of the Grand Duchy and the Republic of Two Nations (i.e., between the fourteenth and eighteenth centuries) Muslims retained their religious autonomy from both local secular and outside religious authorities, though there is sufficient evidence pointing to the Sublime Porte's interest in the well-being of the Muslims of the Republic of Two Nations. ${ }^{7}$

After the final partition of the Republic of Two Nations in 1795, most Tatars of the former Grand Duchy of Lithuania found themselves subjects of the Russian Empire and the local Tatar community was entrusted to the care of the Simferopol-based (Crimea) Mohammedan Spiritual Governing Board ("Таврическое магометанское духовное правление"), which was established in 1794 and led by a mufti. It appears, however, that the Muslims of the lands of the former GDL vehemently insisted on retaining their religious independence. For instance, it is reported as far back as 1803 that Muslims of the northwestern territories of the empire approached the Russian government with a request not to be subjected to the authority of Russia's muftis. ${ }^{8}$ On another occasion, in a letter of 1812, they insisted on their right to choose a mulla from among themselves. ${ }^{9}$ Nonetheless, under the Statute on the Taurida Muslim Clergy promulgated in 1831 and encompassing Crimea and the northwestern territories, all ulama had to meet certain educational and competence criteria and be certified by the Spiritual Governing Board. Unfortunately, it is impossible to assess to what extent the local mullas met the set criteria. Finally, in 1851 the Russian government acceded to the Tatars' requests and officially allowed them to elect

6 Ibid., 172.

7 Dariusz Kolodziejczyk, The Crimean Khanate and Poland-Lithuania: International Diplomacy on the European Periphery (15th-18th Century): A Study of Peace Treaties Followed by an Annotated Edition of Relevant Documents (Leiden: Brill, 2011).

8 Tamara Bairašauskaité, Lietuvos totoriai XIX amžiuje (Vilnius: Mintis, 1996), 130-131.

9 Kričinskis, Lietuvos totoriai, 168. 
mullas from among themselves, though they still needed to be certified by the Spiritual Governing Board. ${ }^{10}$ An attempt by some local Muslims in the middle of the nineteenth century to convince the Russian government to establish a separate spiritual governing body (muftiate) for the Muslims of the western provinces, however, failed miserably.11

In the end, the fact that the headquarters of the formal religious authority, the Spiritual Governing Board, was several thousand kilometers away, made effective communication (and control) practically impossible and the real authority of the generally very reluctant Crimean muftiate over the Tatars in the northwestern territories of the empire remained tenuous and minimal until the end of Russian rule in Lithuania during World War I. Ultimately, Russian authorities' designs and desires to use muftiates in the form of spiritual boards established from above, as tools to control the empire's Muslim subjects had little practical outcomes in regard to Tatar Muslims in the lands of the once Grand Duchy of Lithuania; they survived as an insular community of interrelated but independent congregations into the twentieth century.

\section{Muslims in Interwar Lithuania: The Distribution and Visibility}

In early 1918, in view of the inevitable end of World War I the national(ist) elite in Vilnius (then German-occupied Lithuania) proclaimed its independence, though the definitive formation of a sovereign state took shape several years later after all adversarial forces were finally repelled and the borders of the new state were secured. This was the first time that a Lithuanian nation-state was founded and a Lithuanian nation with the titular Lithuanian ethnicity came into being. Hitherto, ethnic Lithuanians were either a political or a statistical minority in the consecutive state formations they were living in. As was common elsewhere in Europe at the time, the birth of a nation and a nation-state went hand in hand in Lithuania too. ${ }^{12}$ All other ethnic groups living in the territory of the

10 Высочайше утвержденное мнение Государственного Совета 8 января 1851 г. об избрании мулл в магометанских обществах Западных Губерний [The opinion of the State Council of 8 January 1851 on the election of the mullahs in Mohammedan communities of the Western Provinces approved by His Majesty], at http://constitutions.ru/ archives/3239, accessed 10 April 2011.

11 Bairašauskaitè, Lietuvos totoriai, 138-139.

12 For more on the birth of the modern Lithuanian nation and the state, see Alfred Erich Senn, Lithuania Awakening (Los Angeles: University of California Press, 1990). 
new state had to define their relation with the state and titular ethnicity and thus profoundly redefine their identity. This was as true of Jews, Karaims, Poles, Russians, Germans, as of Tatars, especially the Muslims among them. ${ }^{13}$

As has been indicated above, the bulk of the Lithuanian Tatars had traditionally been living in the vicinity of Vilnius, the historical capital of the Grand Duchy of Lithuania - this is where they were given land by the Lithuanian rulers and where they founded their villages. In the aftermath of World War I, in 1920, the region of Vilnius was, however, occupied ${ }^{14}$ by Poland and most of the 'Muslims of the GDL' (some six to seven thousand ${ }^{15}$ ) became Polish citizens. Under Polish rule, Vilnius (Pol. Wilno) became the spiritual and cultural center of the Muslims of the newly established Polish Republic. It is there that an official Muslim organization, the Muftiate, whose purpose was to unify some two dozen Muslim congregations scattered around Poland under one representative institution and thus gain bargaining power vis-à-vis state authorities and other faith communities, was finally founded at a convention of delegates of Muslim congregations in late 1925. Dr. Jakub Szynkiewicz, a graduate of Berlin University, who was well versed in Islamic studies and spoke both Arabic and Turkish, was elected the first (and, as it later turned out, until World War II, the only) mufti of Muslims living in the territory of the newly independent Polish state. The fact that Szynkiewicz was not a classical alim but a Europeaneducated orientalist appears not to have prevented the congregations from electing him mufti and, in the absence of other promising candidates, actually made him the only suitable nominee. Moreover, Szynkiewicz appears to have been the only one of his kind not only among the Muslims of Poland but also among all the Tatars in the territories of the former GDL- there was no one of similar stature in either the Republic of Lithuania or Soviet Byelorussia. This naturally made Szynkiewicz the only "proper" authority among Polish Muslims at least until several younger Tatars were sent to study at al-Azhar in Egypt.

13 A number of Tatars converted to Christianity in the nineteenth century and consequently they and their progeny ceased to be considered by the Tatar Muslims as Tatars. Consequently, most of such non-Muslim Tatars eventually began to identify with one of the larger local ethnic groups-Russian, Polish or Lithuanian. For this aspect of the changes in Tatar identity, see Bairašauskaitè, Lietuvos totoriai XIX amžiuje, 171-181.

14 The Polish administration of the city of Vilnius and its region between 1922 and 1939 was at the time and is still considered by the Lithuanian state as an act of occupation. Lithuania remained in a state of war with Poland until 1938, when diplomatic relations were finally established but tensions between the states remained.

15 Ali Miskiewicz, Tatarzy polscy 1918-1939. Zycie spoteczno-kulturalne i religijne (Warsaw: PWN, 1990), 58-6o. 
Meanwhile, in comparison, imams in independent Lithuania throughout the interwar period remained self-taught.

The Muftiate actively participated in drafting and lobbying for a new law governing the relationship between local Muslim communities and the state, and in the spring of 1936 the Polish state passed this law. According to the law, communities were awarded self-rule - they had the right to elect their mullas/ imams and muazins. ${ }^{16}$ The Muftiate was thus officially recognized by the state as the representative of Poland's Muslims, in this way the Tatar community was recognized as an autocephalous faith community.

As the Vilnius region remained under Polish control until the beginning of World War II in September of 1939, the development of the Vilnius Muftiate as well as the Muslim congregations in and around the city until then can rightly be regarded as part of the history of Islam in Poland. And only between October 1939, when the region of Vilnius was given to the Lithuanian state by the Soviet Union (which was then occupying the eastern part of the former state of Poland), and the summer of 1940, when the Soviet Union finally swallowed all of Lithuania, the three Lithuanian-speaking congregations and three Polish-speaking congregations, including the one in Vilnius, were (re)united in a single state.

The 1923 census revealed that $1,107^{17}$ inhabitants of the Republic of Lithuania (excluding those possibly, though but unlikely, residing in the newly incorporated Klaipeda Region (Memelland), and, naturally, the Polish controlled southeastern part with Vilnius) identified themselves as Muslims. Of those, 1,098 were Lithuanian citizens (two Polish, seven Soviet citizens ${ }^{18}$ ). In terms of self-identification, 961 Muslims identified themselves as ethnic Tatars, ${ }^{19}$ of 146 non-Tatars 117 identifed themselves as Lithuanians (sic!), ${ }^{20} 12$ as Polish, ${ }^{21}$ one as

\footnotetext{
16 Kričinskis, Lietuvos totoriai, 170.

17 Lietuvos gyventojai: 1923 m. rugsèjo 17 d. surašymo duomenys (Kaunas: Centrinis statistikos biuras, 1925), 34 .

18 Ibid.

19 Ibid., 47.

20 Ibid., 38. It is plausible to assume that at least some, if not the majority of these 117 'Lithuanians' were in fact ethnic Tatars, who for reasons that remain unclear, chose to identify themselves as Lithuanians. If this was the case, it would be an interesting aspect of the Lithuanian Tatars' identity transformation, as it can be safely assumed that in earlier times Tatars would have been unlikely to have identified themselves as ethnic Lithuanian Muslims. It also could have been the case that some of those 117 sincerely believed that they were ethnic Lithuanians, though their origin might have been, if only partially, Tatar. 
a Turk, ${ }^{22}$ while the remaining considered themselves Russians, and five ${ }^{23}$ failed to identify their ethnic belonging altogether. There were three areas with large concentrations of Muslims in interwar Lithuania and two with smaller numbers, chiefly in the eastern and southern parts of the country. By far the largest number, $73^{2}$ in 1923, lived in villages and other small settlements in the southern Alytus district. ${ }^{24}$ The second largest, with 122 , lived in the Trakai district. ${ }^{25}$ The number of Muslims in the interim capital Kaunas and nearby villages was just a little over one hundred ${ }^{26}$ with one third (37 individuals) identifying as Lithuanians (sic!). ${ }^{27}$ There were also smaller groups of Muslims in Vilkmerge (44 persons) and Zarasai ( 56 persons) districts. The census results clearly show that the overwhelming majority of Lithuanian Tatars at the dawn of Lithuanian independence were based in rural areas with just around ten percent living in urban areas, chiefly the interim capital Kaunas.

Arguably, the most visible sign of Muslim presence (and belonging?) in an area are mosques, especially purpose-built, and cemeteries. Since the majority of the region's Tatars traditionally lived in the countryside, most of their mosques, around which religious life revolved, were situated in villages rather than cities. By the beginning of the twentieth century in the territory of the former GDL only a dozen mosques remained. Only two of the historic Tatar mosque buildings were situated in the territory of interwar Lithuania, one, built in 1889, in the village of Raižiai (Alytus district, some 70 kilometers south of the interim capital Kaunas), another, built in the 1820s, in the village of Vinkšnupiai (some $8 \mathrm{o}$ kilometers southwest of Kaunas), though this one had been damaged during World War I and reportedly remained in bad shape throughout the interwar period as there were no funds (and apparently no need) to repair it. In the city of Kaunas itself a new brick mosque (the only one of its sort in Lithuania to this day) was built on the spot of a former makeshift mosque and opened its doors to worshipers in 1932. Naturally, there were mosques in Vilnius and nearby villages (like Niemież/Neméžis, Sorok Tatary/Keturiasdešimt Totorių) but these were technically in Poland of the time.

\begin{tabular}{ll}
\hline 22 & Ibid., 48. \\
23 & Ibid. \\
24 & Ibid., 36. \\
25 & Ibid. \\
26 & Ibid. \\
27 & Ibid., 38.
\end{tabular}


Prior to the emergence of sovereign nation-states, the overwhelming majority of the 'Tatars of the GDL' throughout their history lived in one state-be it the Grand Duchy itself, the Republic of Two Nations, or the Russian Empire-and thus naturally perceived themselves and each other as belonging to the same single community, albeit dispersed over a relatively large territory. The founding of the nationalistically orientated and even mutually antagonistic independent states of Lithuania and Poland (and also of Soviet Byelorussia) almost by default obliged the Tatars to publicly redefine their identity and belonging. Even more so-members of the same families often found themselves citizens of different countries with ensuing exclusivist loyalties and allegiances, something that frequently happened also to other, more numerous, ethnic groups, like Poles, Lithuanians, Russians, and Belarusians. The most symbolic instance of this was the fate of the members of the Narutavičius/Narutowicz family, in which one brother became a signatory of the Lithuanian Independence Act of 1918, while the other brother became the first Polish president in 1922.

Those Tatars who, after all the commotion and border changing in the early 1920s, found themselves in the territory of the Republic of Lithuania, had to come to grips with the new reality — not only had they become a tiny ethnoconfessional minority in the Lithuanian nation-state, but they had also been cut off from their related congregations and their centuries-old demographic and spiritual center, Vilnius. This newly emerged factual situation demanded that the Lithuanian Tatars define their identity and relations with the outgroups (the majority society but also Tatars in the neighboring countries, foremost Poland) anew. This was made even more urgent by the seemingly permanent state of war between Lithuania and Poland over the Vilnius region; a state of war that lasted until 1938, when the two states finally established diplomatic relations. Thus, for much of the interwar period both Tatar communal relations and relations with the state authorities should also be viewed through the prism of Lithuanian-Polish relations. So, rather than lamenting the fate which had dismembered the hitherto single community with numerous intra-communal kin relations, the Lithuanian Tatars appear to have publicly expressed joy at having become inhabitants of Lithuania rather than Poland, even if the latter would have meant keeping the bulk of the Tatars in a single state. Many of the surviving documents (in the form of letters from Tatars to the Lithuanian state institutions) vividly attest to this.

In any case, it was in interwar Lithuania that for the first time in history a distinct outward Lithuanian Tatar (different from and even opposed to the Polish and Belarusians) identity was born. In their correspondence to the state 
authorities, the leadership of the Tatar congregations routinely claimed to be loyal citizens of the Lithuanian state and the nation: "in general, in the mass of the Lithuanian Mohammedans, there are no sympathies for Poland, and quite to the contrary, the Lithuanian spirit prevails, Mohammedans do well joint Lithuanian work by taking part in patriotic organizations and the union for the liberation of Vilnius, serving in the armed forces." ${ }^{28}$ In a letter dated 27 October 1939 (when the Vilnius region had already been given by the occupying Soviets to Lithuania), its authors ("a group of Lithuanian Mohammedans") argued that

Lithuanian Mohammedans are not Polish and any Polish influence needs to be eradicated and Poles are not to be given a chance to interfere in our, Lithuanian Mohammedans', faith matters. The extermination of the Polish influence will not at all harm Mohammedans because they are not Poles. In general, Lithuanian Mohammedans do not feel any sentiments toward Poland, and quite to the contrary: they, like all Lithuanians, do common Lithuanian work, participate in various organizations, serve in public offices and armed forces. ${ }^{29}$

Financial support from the state, as evident from many of the surviving documents, must have also played an important role in the Tatars' public rhetoric, especially around the time of the construction of a new mosque in Kaunas in the 1930s, as shown below.

A significant aspect of this identity construction is the Tatar adherence to the cult of Vytautas the Great, the duke who has long been regarded in Lithuania as one of the most important and praiseworthy rulers of the Duchy and who is the single most prominent figure in the Lithuanian Tatar myth of origin, which credits him with bringing the Tatars to the lands of the GDL. For instance, in a letter to the Minister of Education, dated 6 April 1930, ${ }^{30}$ in which the Tatars solicit financial assistance from the state to build a new mosque in Kaunas, arguably in commemoration of the 500-year anniversary of Vytautas' death, the authors of the letter began by paying tribute to Vytautas, whom they called "the hero, whose name is dear to us, Tatars." The authors of the letter went so far as to promise to name the new mosque after Vytautas, who incidentally was not only never a Muslim, but also appears to have remained pagan even after being christened twice as a Catholic. If, in the case of the mosque financing, one might regard the

\footnotetext{
28 391-4-1845-11.

$29391-4-1846-46$.

3о $391-4-148-2,-2 a p$.
} 
Tatar praise of Vytautas as mere rhetoric in the cause of pleasing state authorities and gaining their favor, then in a lengthy handwritten letter to the Minister of Education, dated 29 December 1939, sent by the Raižiai Tatars, their sincere admiration for Vytautas can hardly be doubted. In the letter, the authors went to great lengths to remind the minister of the long and glorious Tatar history in Lithuania by closely linking it with the person of the Grand Duke Vytautas: they claim to be "descendants of those courageous and honorable soldiers, who took part in the army of Vytautas the Great" and also that "the Lithuanian Tatars, soldiers of Vytautas the Great, out of their own free will pledged loyalty to Lithuania with their swords and to this day we stand by that pledge and honorably fulfill it. We, the Lithuanian Tatars, Lithuania's sons, are ardently attached to it." ${ }^{31}$ The authors further claim that Lithuanian Tatars, "out of respect for Vytautas the Great, mention his name in their prayers" (sic!). ${ }^{32}$ Though in the surviving archival material it is not used as an argument, it is worth noting that the historical Vytautas is reported to have been opposed to his cousin Jogaila's (Pol. Władysław II Jagiełło) marriage to a Polish princess and becoming a Polish king and thus uniting the Grand Duchy of Lithuania and the Polish Kingdom through their personal union. For this stance, in Lithuania Vytautas is almost universally held up as a defender of Lithuanian independence and contrasted with Jogaila's purported treason. In the context of animosities between Lithuania and Poland during the interwar period, this aspect of Lithuania's history was particularly stressed by Lithuanian historians of the time. ${ }^{33}$

In their correspondence to state authorities, the Tatars not only identified themselves with the Lithuanian state but also claimed to be identical with ethnic Lithuanians in all but faith: "Now we are different only in religious rituals and festivities." ${ }^{4}$ After the Vilnius region became part of the Lithuanian Republic in late 1939, even the leadership of the Vilnius-based Muslims (especially in the person of the Mufti Jokūbas Šinkevičius, his name, which he himself now spelled according to the Lithuanian transliteration) identified themselves with the Lithuanian state and the nation. In a letter to state authorities written on 25 January 1940, Šinkevičius claimed to be happy that the Vilnius region had been reunited with mother Lithuania:

\footnotetext{
$31 \quad 391-4-1846-29$.

32 391-4-1846-29ap, 30, -30ap.

33 For portrayal of the relations between Vytautas and Jogaila in history textbooks, see a semi-official seminal volume, A. Šapoka, Lietuvos istorija (Kaunas: Book Publishing Commission of the Ministry of Education 1936), 102-150.
} 
Lithuania's independence blossomed in all its greatness in the old, Lithuanian capital founded by the grand dukes in the eternal sanctuary Vilnius! We had been waiting for 19 years longing for our true masters to enter the Lithuanian Vilnius region and the old capital-Vilnius. What we had been waiting for for 19 years, has happened! Truth has won! Truth and right are alive! The thrill of joy went through all Lithuanian Tatars! Lithuanians entered their capital not only as its permanent master but also as a true mother of this Lithuanian land! While regaining the capital, we receive her like an eastern dawn of the new times for the new achievements of the Lithuanian nation.

We pray for the freedom and well-being of Lithuania! We have grown together organically with the history of the Lithuanian nation, we are Tatars of Lithuania. We add our voice to the voice of our beloved brother Lithuanians! It is worth working and living! It is worth building such life that the Lithuanians and the Lithuanian Tatars become even closer brothers, that happiness ruled in our motherland Lithuania! How terrible it was when brother was separated from brother. ...In this land, where the true masters are the Lithuanians, some violent people, some invaders were "lords," however...they perished! They wanted to separate the Lithuanian Tatars of the Vilnius region from the Lithuanian Tatars and Lithuanians living in free Lithuania and sought to Polonize them. However, the Tatar masses sincerely rejected such "works" and in the passport of every Tatar it was written: Lithuanian Tatar. ${ }^{35}$

Though it is highly plausible to suspect that the mufti expressed his (and the Tatars' of the Vilnius region) loyalty to the Lithuanian state and nation only instrumentally (further in the letter he pleads with the minister to found a "Muslim Muftiate" in Vilnius and provide for the salaries of the "clergy"36), his words are nonetheless symptomatic of the situation of the wider Tatar community, which by virtue of being a negligible and weak minority needed to repeatedly reconfirm its identification with the state and the nation in the territory in which it found itself. The Tatars of the Vilnius region once again had to reconstruct their identity and this time it must have been even more difficult, for as I show further below, the Tatars of the Lithuanian provinces were far from welcoming toward their co-religionists. 
Though relatively dispersed, organizationally Muslims in interwar Lithuania (before the Vilnius region became part of it) had three independent and physically rather distant congregations (which they called 'parishes'), centering on the surviving mosques-the most numerous the Raižiai Mohammedan ${ }^{37}$ Parish in Alytus District, Kaunas Mohammedan Parish (in 1936 registered as Kaunas Muslim Society), and the smallest of them Vinkšnupiai Mohammedan Parish (though the 1923 census hardly registers a Muslim presence in that part of the country). Out of inertia and tradition, congregations continued to elect their own spiritual leaders (internally called mullas). So, for instance, Kaunas Mohammedan Parish unanimously elected a new 'parish priest (mulla)' in 1922 after the previous one had died, ${ }^{38}$ and he officially introduced himself as the 'rector of the parish.' 39

Despite the fact that there had never been any significant Muslim presence in Kaunas, after it became the capital of Lithuania, local Muslims registered a religious community there in the fall of 1923 and by the second half of 1925 came up with a plan to establish a Faith Organization of Lithuanian Mohammedans which would supervise and coordinate the religious activities of all the Muslim congregations in the Republic of Lithuania. It is worth noting that the Muftiate in Polish-controlled Vilnius was established in December of the same year. This coincidence is hardly accidental-Kaunas Muslims must have known of the plans of their co-religionists in Vilnius and might have emulated them. The temporary rules for the supervision of the relations between the envisioned Faith Organization and the Lithuanian government foresaw the seat of its governing body, the Mohammedan Central Council, as being in Kaunas. This council would consist of three members elected by congregation representatives, two per each 150 congregation members. ${ }^{40}$ However, at that time the idea of a central spiritual governing body in Lithuania did not materialize, mainly due to a lack of commitment and the widespread mistrust among the Muslims of the provinces, who made up the majority of Lithuania's Muslims, of the Kaunas congregation's intentions.

\footnotetext{
37 In the interwar period Lithuanian Muslims frequently referred to themselves as "magometonai"—“Mohammedans."

$38 \quad 391-4-1825^{-134}$.

$39 \quad 391-4-1825-117$.

$40 \quad 391-4-1821-75$.
} 

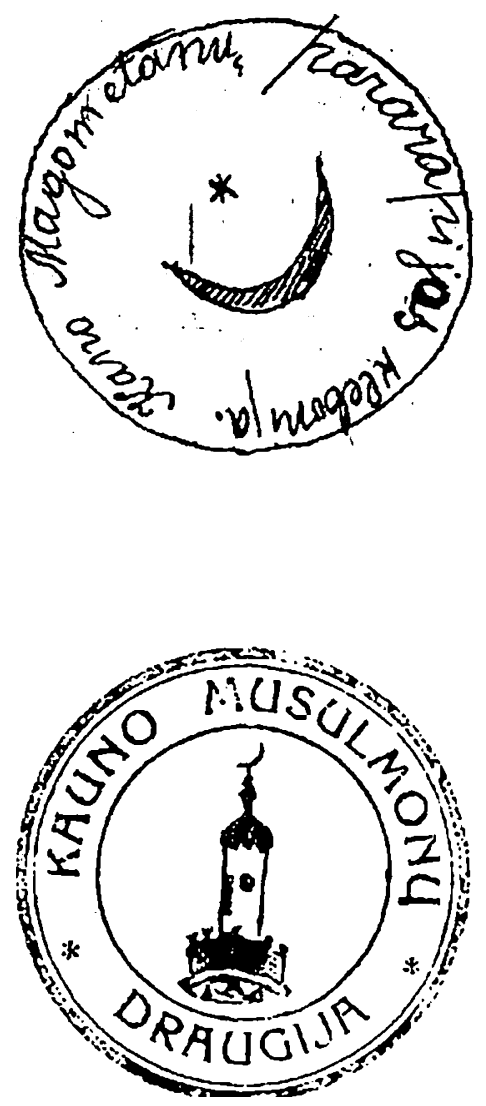

FIGURE 8.1

Sample of the requested stamp of the

Rectorate of Kaunas Mohammedan Parish, ${ }_{3}$ October $1923^{41}$
FIGURE 8.2

Kaunas Muslim Society's stamp, on a document dated 9 September $1937^{42}$

After the local organization's reorganization in 1930 into a purely religious (rather than a confessional Tatar) organization named the Kaunas Muslim Society (officially registered in 1936 and headquartered in the interim capital close to the seat of power), the most active members of the Kaunas congregation apparently had hoped that the relevant state authorities would recognize their new/old organization as the de facto leader among the nation's Muslim congregations and as the center around which provincial congregations should unite. The state appears to have, for a moment, subscribed to this idea and entrusted Kaunas Muslim Society with the supervision of a state allowance and its distribution among the three acting imams. Members of the Society, perceiving themselves as acting on behalf of and in the name of the state, in

\footnotetext{
41 391-4-1821-117.

$42 \quad 391-4-1845^{-48}$.
} 
June 1937 paid an unannounced visit to Vinkšnupiai to inspect the mosque and the cemetery which they later claimed, in their report to the Ministry of Education, to have found in an appalling state - the mosque being in a bad shape and therefore permanently closed, and the cemetery neglected. ${ }^{43}$ Because of this, the Society proposed that the ministry temporarily withhold the allowance from the mulla of the Vinkšnupiai congregation.

Possibly emboldened by the state's sympathetic attitude toward it (especially during the construction of a new brick mosque in Kaunas in 1930-1932, see below), in 1937 Kaunas Muslim Society made a second attempt to unify the Muslim congregations under its leadership; it submitted a request to relevant state authorities for the establishment of a unified Muslim confessional center. In the request, the Society's leadership argued that in the absence of administrative oversight, individual mullas sometimes failed in their duties, could not come to terms to coordinate their activities, and also disregarded advice by congregation members, however, they themselves supposedly realized a need for such a unifying body. ${ }^{44}$ Thus the authors "humbly ask" that the addressed official in charge of religious affairs "takes the initiative into his hands to unite the actions of the mullas by appointing for this purpose one of them as Imam (dean) and entrusting the rest to his leadership." ${ }^{45}$

Internal communication in the Ministry of Education suggests an initial positive reaction and the ministry encouraged Kaunas Muslim Society to prepare a document to serve as the basis for the centralization of the Muslim organizational structure in the country; the Society soon did this. ${ }^{46}$ In its letter accompanying the draft of "The Rules of the Centralization of Muslim Confessional Institutions," Kaunas Muslim Society leadership urged the relevant state authorities (identified as ministries of education and interior) to act promptly as the "founding of a highest Muslim clergy body (Muftiate) is an urgent and necessary matter." 47

The Society's draft of "The Rules of the Centralization of Muslim Confessional Institutions" stated at the outset that the supervision of Lithuanian Muslim confessional institutions "belongs" (direct translation from the original Lithuanian) to the mufti of the Lithuanian Muslims and the muftiate's headquarters should be in the capital of Lithuania, though the document does not

\footnotetext{
43 391-4-1845-37.

44 391-4-1846-40.

45 391-4-1846-40.

$46391-4-1846-36,-36$ ap.

$47 \quad 391-4-1846-36$.
} 
indicate whether the capital is Kaunas (officially perceived to be only a temporary capital) or Vilnius (officially seen as "occupied," yet the only true capital). However, at the end, the rules clarify the situation- "the capital of Lithuania" is meant to be Vilnius. And as long as Vilnius remained in Polish hands, the duties of the mufti were to be conferred temporarily to someone residing in "the interim capital" (i.e., Kaunas).

According to the proposed rules, only citizens of Lithuania, older than 35 years and with higher education were considered eligible for the post which one would occupy after winning elections arranged during the convention of delegates of Muslim congregations. The tenure would be for life. According to the proposed rules, the functions of mufti would comprise spiritual guidance ("interpreting questions of the Islamic faith," "accepting individuals of other faiths into the Muslim faith and setting general rules"), and administrative tasks (controlling the activities of Muslim "clergy" (direct translation from the original Lithuanian), checking registration books maintained by local imams and submitting relevant information to the supervising ministry, "controlling faith instruction," supervising the property of Muslim confessional organizations, arranging the salaries of "clergy" and employees at confessional institutions). Imams (or "clergy," as they are interchangeably called) were to be elected by congregations but would submit to mufti's authority; he would be entrusted with the right to dismiss them.

Unfortunately for Lithuania's Muslims, this second attempt failed also. The provincial congregations (centered around the Raižiai and Vinkšnupiai mosques) rejected the initiative outright and even openly suggested that the despised Vilnius-based Polish Muslim organizations, who were even accused of having sent the very draft of the rules, must be behind this latest attempt by the Kaunas congregation..$^{48}$ For the sake of fairness, one has to admit that the submitted draft of "The Rules of the Centralization of Muslim Confessional Institutions" was conspicuously reminiscent of the statute of the Muslim Religious Union of Poland adopted in Poland in the summer of $1936 .{ }^{49}$ In reaction to the insinuations by the provincial congregations and in view of communal squabbles (described in detail below), the Department of Culture at the Ministry of Education in December 1937 informed the official representative of the Vinkšnupiai congregation in Kaunas that "the question of the centralization of the Muslim faith is for the time being put off." 50

\footnotetext{
48 391-4-1845-10.

49 Bairašauskaitė, "Musulmonų konfesinè bendruomenė," 107.

$5^{\circ} \quad 391-4-1845^{-27}$.
} 
The feeling of independence (but also the short-sightedness caused by provinciality) among the members of the two provincial congregations must have been so entrenched that though minuscule in numbers and surrounded by a majority of people of a different faith, the Lithuanian Muslim community throughout the period of the independent interwar Lithuanian Republic was cursed with permanent self-inflicted disunity. This disunity, in the form of open animosity, appears to have escalated and reached its peak during the Kaunas Muslim Society's renewed attempts to both legally and practically take the reins of Muslim affairs into their hands, starting in 1937. This was the time when the provincial congregations started barraging the relevant state authorities with complaints full of insinuations and conspiracy theories.

The Vinkšnupiai congregation was especially hostile toward the Kaunas Muslim Society. In their August 1937 reply to the report submitted by the Society to the Ministry of Education on the state of affairs in the Vinkšnupiai congregation, the congregation leadership sent a five-page letter in which it accused the Kaunas Muslim Society of exceeding its powers and meddling in the internal affairs of the Vinkšnupiai congregation. ${ }^{51}$ The authors accused (and indeed rightfully) the Kaunas Muslim Society of seeking to subjugate and even include the Vinkšnupiai congregation in the Kaunas congregation. ${ }^{52}$ They further charged the Society with sowing discord both inside the Kaunas congregation itself and among the Muslims of Lithuania and argued that the Society should not be seen by the state as the representative of Lithuania's Muslims. ${ }^{53}$ Finally, the Vinkšnupiai congregation requested (though it reads more like a demand) that the ministry cease transferring allowance money to the Society and rather resume the earlier practice of disbursing it directly to imams. ${ }^{54}$

Almost the same accusations that were leveled at the Kaunas Muslim Society were reiterated in a shorter letter later (written in September 1937), this time signed by representatives of both provincial congregations. ${ }^{55}$ This suggests that the two congregations joined their efforts in their fight against the perceived hegemony of the Kaunas Muslim Society. In this particular letter the authors argued that the two provincial congregations were centuries old and had always

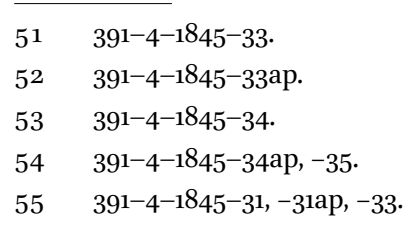


been independent in their spiritual affairs with imams elected locally, something that the Kaunas congregation, being a new formation, lacked. ${ }^{56}$ In the letter, as in the previous letters, the Society was called a small private organization with its membership consisting of relatives and therefore the claim was made that it was not representative of the wider Muslim population in the country.

Finally, at the end of the same year, Aleksandras Chaleckas, the representative of the Vinkšnupiai congregation in Kaunas, wrote yet another similar five-page letter to the Minister of Education, reiterating most of the earlier accusations leveled at the Kaunas Muslim Society and at the same time addressing, from the perspective of the Vinkšnupiai congregation, the issues raised in the report of the Society's fact-finding mission. ${ }^{57}$

Further intra-congregation hostility is displayed openly in numerous subsequent letters from provincial congregations to the state authorities. In one of them, an anonymous letter dated as late as 28 October 1938, the Kaunas congregation was bluntly called "a real and unbearable misunderstanding among Mohammedans." 58

The animosity between the congregations based in the capital and the provincial congregations crossed the limits of a simple internal power struggle and was intentionally extended by the provincial congregations to include the question of the congregation's position on and relations with the citizens of the arch enemy-Poland. The provincial congregations went so far as to accuse the Kaunas based Muslim activists of treason because of their alleged cooperation with the Vilnius-based Muslims. For instance, in their aforementioned lengthy letter to the Minister of Education written on 28 October 1938, and marked "Secret," its authors claimed that the Kaunas Muslim Society was maintaining close relations with Muslim organizations ("Związek kulturalno oswiatowy" and "Muftiat"), based in occupied Vilnius. At the purported instigation of these Polish organizations, with which they supposedly "had secret relations," and from which they "used to receive instructions," activists of the Kaunas Muslim Society "would engage in various intrigues and misunderstandings among Mohammedans, fighting this way with the Lithuanian spirit of Mohammedans and with this very much obstructed the execution of useful work." ${ }^{59}$ The Kaunas Muslim Society was deemed to have received advice from the Polish side to "try and take under its tutelage Mohammadan parishes and

\footnotetext{
$5^{6} \quad 391-4-1845^{-} 31$.

57 391-4-1845-28, -28ap, -29, -29ap, -30 .

58 391-4-1845-9.

$59 \quad 391-4-1845^{-10}$.
} 
create a central Mohammadan organization made purely of Polephiles (Lith. lenkomanai)." 60

The provincial (in this case, Vinkšnupiai) congregations must have been convinced that Muslims based in Vilnius harbored ill will for those living in Lithuania. They alleged that as a Polish organization the Vilnius Muftiate was more a political organization and a tool in the hands of the Polish state than a faith-based institution: the Muftiate and its affiliated organizations are charged with having "secret political goals and work" which they (the Polish Muslim organizations) and "their agents cover and dress in supposedly Mohammadan faith matters," ${ }^{\prime 1}$ while in reality "the special purpose" of these organizations was "to Polonize Mohammedans in Vilnius and elsewhere and to look for a means to bind the Lithuanian Mohammedans to Polish organizations." 62

Though it cannot be read directly from the available archival material, one might conclude, hypothetically, that because of their low level of religious and other education and lack of erudition and because of their somewhat heightened concern to preserve their independence and purity from foreign influences, let alone control, the Muslims of interwar Lithuania, unlike those of Poland, did not seek closer cooperation or integration with the Muslim communities elsewhere in Europe or in Muslim-majority states. There is very little evidence to suggest that Lithuanian Muslims tried to approach their co-religionists abroad. One such rare occasion can be found in a letter in the fall of 1933 written by Chaleckas, the imam of the Kaunas mosque, to the Moslemische Revue, a German language Ahmadi periodical, informing the editors of the opening of a new mosque in Kaunas. In its October 1933 issue Moslemische Revue published a short note on the opening of the Kaunas mosque, indicating that the information was drawn from the received letter. ${ }^{63}$ It remains unclear if such a letter had been sent to other Muslim organizations or publications elsewhere and whether the Lithuanian Muslims were aware of Moslemische Revue's Ahmadi nature.

The lack of evidence of transnational communication, let alone cooperation, between Lithuania's Muslims and those elsewhere in (western) Europe during the interwar years suggests that the Lithuanian Tatars were preoccupied with other issues they deemed more urgent and relevant. The identity

\footnotetext{
6 o $391-4-1845^{-10 .}$

$61391-4-1845-9,10$.

62 391-4-1845-9.

63 “Eine Neue Moschee zu Kaunas in Litauen," Moslemische Revue (Oct. 1933), 91-92.
} 
shifts the Tatars of the former GDL went through after the break-up of the Russian Empire initially took most of their efforts. Afterwards, attempts and the constant failures at institutionalization caused by the demographic distribution of Tatars and intra-communal relations prevented the avant-garde of Lithuania's Muslims based in Kaunas from forging long-term relations with Muslims in Europe, let alone in the wider world. From this perspective, one can only lament that though the Lithuanian Tatar community had been, by the beginning of the twentieth century, one of the oldest Muslim communities that had lived in Europe continuously, it failed to tap into the newly forming vibrant and complex transnational networks of Muslims in interwar Europe, something that undoubtedly would have significantly enriched the local community.

6

Developments after the Regaining of the Vilnius Region

The Soviet occupation of the eastern part of the Polish Republic in the first month of World War II (which began on 1 September 1939) led, on 10 October 1939, to the Vilnius region (with its significant Muslim community, estimated at some $670,{ }^{64}$ and home of the Muftiate) being given by the Soviets to Lithuania. After regaining the Vilnius region, the number of Muslim congregations in Lithuania doubled to six. The Kaunas Muslim Society then made a final attempt to unify these congregations under one umbrella organization. In their "Memorandum" of 29 November 1939 to the Minister of Education they called on the minister to either promulgate the 1937 "Rules of the Centralization of Muslim Confessional Institutions" or solve the problem in some other way. ${ }^{65}$ This last attempt appears to have been welcomed by the Raižiai congregation, which had apparently switched sides and which in its letter of 29 December 1939 not only urged the Minister of Education to move quickly in solving the lasting impasse but was also full of praise for the mufti who, it claimed, was "full of love to Mohammedan-Muslim faith and Lithuania, his motherland."66

However, the Vinkšnupiai congregation remained unwavering and renewed its bombardment of state institutions with letters of complaint about the perceived intentions and activities of the Vilnius-based Muslim leadership, chiefly manifest in the person of Jokūbas Šinkevičius/Jakub Szynkiewicz. In his letter

\footnotetext{
64 Bairašauskaitè, "Musulmonų konfesinė bendruomenè," 110.

$65391-4-1846-41$.

66 391-4-1846-30.
} 
of 17 November 1939, the representative of the Vinkšnupiai congregation in Kaunas pleaded with the Ministry of Education not to allow the reopening of the Muftiate. ${ }^{67}$ In their later letter, coincidentally (?) dated the same day (29 December 1939) as the supportive Raižiai letter, several members of the Vinkšnupiai congregation argued that "for many years we did joint Lithuanian work not so that now, after regaining the Vilnius region, we would import Polish leaders for ourselves and even foreigners (Jakub Šinkevič)... and all sorts of troublemakers" and suggest that these "mind their own business." ${ }^{\text {" }}$ Just a day later (30 December 1939), in another and more detailed letter, several representatives (some of them the same as in the letter a day earlier) of the same Vinkšnupiai Mohammadan Parish argued that "Lithuanian Mohammedans do not want any Polish leaders to be their go-between (Janušauskai, Vilčinskai from "Kaunas Muslim Society") and we protest against the work of them all." The authors were adamant: "We did not do patriotic Lithuanian work for 20 years to put on ourselves the noose of Polish leaders now, after having regained Vilnius (???)." In the end, they even issued a judgment on Šinkevičius' / Szynkiewicz's prospects of receiving Lithuanian citizenship: "The above mentioned Jakub Šinkevič [Jakub Szynkiewicz] cannot be a citizen of Lithuania, because he was born in the town of Liachovičiai [Lachowicze], close to Baranovičiai [Baranowicze], and his friends want to import him to us." ${ }^{\prime 9}$ Finally, the authors pleaded with the minister to "definitively close the aforementioned Polish organizations ("Muftiat"), not to give any money to Polish leaders and to prevent their interference in our affairs." ${ }^{70}$

Despite these protests by the Vinkšnupiai congregation, in January 1940, local authorities in Vilnius allowed the Muftiate to operate unofficially until it "obtains the permit to operate legally."71 At the end of January Šinkevičius approached the Minister of Education with a letter requesting that the Muftiate be reopened and that funding for the salaries of its employees be allocated. ${ }^{72}$ The imminent annexation of Lithuania in the summer of 1940 by the USSR and subsequent occupation by Germany made all this impossible. However, Šinkevičius/Szynkiewicz remained in Vilnius throughout the Nazi occupation until 1944, when, in his capacity as the spiritual head of the Muslims in the area

\footnotetext{
$67 \quad 391-4-1846-42$.

68 391-4-1846-50.

69 391-4-1846-48ap.

$70 \quad 391-4-1846-49$.

71 401-2-160-17, 18.

72 391-4-1846-22, 22ap.
} 
and in the wake of the Soviet return of Lithuania, he emigrated first to Egypt and later (in 1957) to the United States where he died in $1966 .{ }^{73}$

\section{The State's Position}

The constitutions (all of them, in 1922, 1928, and 1938) of interwar Lithuania affirmed general religious freedom. However, no further legal regulations between the Lithuanian state and its Muslims were promulgated and practical relations between them appear to have been based more on moral commitment and goodwill from the state's side than on formal obligation. It was primarily the Department of Faiths at the Ministry of Interior, and later, in the 1930s, the Department of Cultural Affairs at the Ministry of Education that were charged with the supervision of religious affairs and represented the state in dealings with the Muslim congregations. Ultimately, most of the documents preserved at the Lithuanian State Archive are either letters by Muslims addressed to one of these departments or their replies to the queries from Muslims.

The communication (and the cooperation stemming from it) between the relevant state institutions and the Muslims in the interwar period, in which the state's position vis-à-vis the country's Muslims can be discerned, can be divided into three areas: (a) continuous financial support for congregations in the form of allowances for imams; (b) financial support for building a new mosque in Kaunas; and (c) expected state arbitration in the relations among the Muslim congregations.

With regard to the allowances, in June 1929, Kaunas Mohammedan Parish approached the prime minister with a request to "assign permanent salary" for the congregation's imam (in the document called “dvasiškis," or "clergyman"). ${ }^{74}$ The petitioners based their request on the fact that though the former clergyman would be content with the 100 litas allowance provided by the Department of Faiths and would serve as the imam "out of dedication, without requiring a separate salary," with his passing away, the congregation, on its own, "without the state's support...in no way can sustain a clergyman." The request was received favorably and dealt with promptly (on the same day as it arrived at the prime minister's chancery) by Prime Minister Augustinas Voldemaras personally, who in his handwritten resolution on the very same letter sympathized

73 Adas Jakubauskas, Galimas Sitdykovas, Stanislavas Duminas (eds.), Lietuvos totoriai istorijoje ir kultūroje (Kaunas: Lietuvos totorių bendruomenių sajunga, 2012), 148. 
with the local Muslims. ${ }^{75}$ Ultimately, the state resolved to pay modest semiannual allowances to the imams of all three parishes. ${ }^{76}$

The Tatars professed loyalty to the state and were generously rewarded by the government - it provided the bulk of the funding for a new (to this day the sole) brick mosque in the interim capital Kaunas; the mosque opened its doors to worshipers in 1932. Though initiated by the Kaunas Tatars in 1930, ${ }^{77}$ they saw the financial burden of bringing the mosque from its inception to completion as the state's responsibility. Local Tatars (in the letter their numbers are given as 200 in the Kaunas region with just 70 in city of Kaunas itself ${ }^{78}$ ) could not have expected to collect the needed amount (originally estimated at a staggering 85 thousand litas), thus they immediately proceeded with lobbying the minister to make the funds available. The Kaunas mayor and other relevant authorities approved of the construction..$^{79}$ In the end of the same year the Tatars once again requested 25 thousand litas from the state for the completion of the mosque, citing their failure to raise additional funds from within the community. 80

Though the surviving archival material does not allow one to speculate as to what extent the Lithuanian government wanted to control and even meddle in the internal affairs of the local Tatar community, the fact of Lithuania's state of war with Poland over Vilnius and its region must have weighed on the Lithuanian government's position both toward its Tatar community and especially this community's relations (ties) with their co-religionists in Poland, especially the Vilnius region. As shown above, the two provincial congregations bombarded the relevant government authorities about the perceived treason of the Kaunas Muslim Society in favor of Poland. However, it appears that the government, in spite of the wishes of the provincial congregations to avoid dealing with the Kaunas Muslim Society, chose a path of pragmatic cooperation with it. One might even argue that the government's reaction in the form of its dealing with and treatment of the Kaunas Muslim Society suggests that the state authorities rather saw in it a partner and even a possible national leader of all of Lithuania's Muslims. And it was only under pressure from the provincial congregations that the government tacitly withdrew its open support for the Society.

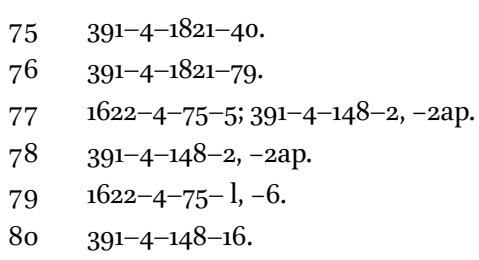


After establishing control over the lands formerly held by Poland, the Lithuanian authorities outlawed all Polish-registered organizations, including the Muftiate and its premises, which were locked and sealed. ${ }^{81}$ However, after intense lobbying by the Kaunas Muslim Society (now supported by the Raižiai congregation) and Mufti Šinkevičius (who, by the way, had been denied Lithuanian citizenship ${ }^{82}$ ) personally, the authorities allowed Šinkevičius to resume his functions for a time, though without pay or office; in this way they showed some sympathy for the Tatar cause, both in the sense of fulfilling their spiritual needs and communal unity.

\section{Conclusion}

The interwar period was in practice the time in which the local Tatar Muslim community, which consciously identified itself with the Lithuanian nationstate (in contrast to its earlier identification with the Grand Duchy of Lithuania, which had covered parts of Poland, Belarus, and Ukraine), was born. This identity was closely tied to the myth of origin and settlement stories in which the bravery and loyalty of the Tatars in the army of Vytautas the Great and his gratitude to the Tatars were central. At the same time, the community appears to have shown little interest in the outside world or Muslims living elsewhere, either in Europe or further afield. The more numerous provincial congregations took an insular stance and did not pursue transnational communication, let alone cooperation, with Muslim communities and organizations abroad; this facilitated the community's overall provincialism, lack of familiarity with, and remoteness from contemporary processes in the religious sphere of the world's Muslims, namely reformism and revivalism.

In spite of this unitary narrative of belonging to and in the land, and unlike their co-religionists in Poland, in the interwar period the Muslims (especially those based in the provinces) of the Republic of Lithuania failed to realize a need for or see the benefit in a greater institutionalization of Islam in its territory and instead continued with the tradition of independent congregations (parishes), a tradition they had inherited from the times of the Grand Duchy of Lithuania, and resisted centralization and institutionalization very much like they had in Russian times. In Bairašauskaite’'s opinion, ${ }^{83}$ the part of the original community of the 'Muslims of the GDL' which found itself within the borders of the Republic of Lithuania was intellectually not advanced.

$\begin{array}{ll}81 & \text { Bairašauskaitė, "Musulmonų konfesinè bendruomenè," } 111 . \\ 82 & \text { Ibid., } 112 . \\ 83 & \text { Ibid., } 105 .\end{array}$ 
This certainly appears to be true in the case of the provincial congregations; however, the core that comprised the Kaunas Muslim Society seem to have been 'progressive'- they not only sought to unite Lithuania's Muslims under a single umbrella organization and thereby raise the standards of Islamic practices, but had an even broader vision and were also open to cooperation with the Vilnius-based Muftiate. In this regard, the Muslims of the interim capital, or at least the most active among them, and the provincial Tatars had rather divergent perspectives on the development of the Lithuanian Muslim community. As Bairašauskaite ${ }^{84}$ correctly points out, "contradictory positions of Muslim parishes were caused by inner competition and different political attitudes, which were obstacles for making decisions on creation of confessional center." At the same time, with no pressure (or support) from above (e.g., state authorities), there were no interested players strong enough to organize Lithuania's Muslims into a coherent faith community that would have mirrored the one in interwar Poland.

The stubbornness of the Vinkšnupiai congregation and its bickering with the rest of Lithuanian Muslims lasted to the very end, when in the summer of 1940, the Soviet Union occupied and annexed all of Lithuania, thus terminating the state's and also the Muslim community's independent existence. World War II dealt a final blow to the Vinkšnupiai congregation-its mosque was destroyed by German troops, its members uprooted and dispersed. Today, only the cemetery remains as a reminder of the tiny yet unwavering western-most congregation of Lithuanian Tatars.

The story of the interwar Lithuanian Muslim community presented above remains, however, incomplete. This is a result of the scarcity of archival and other research material. On the other hand, there are still some living witnesses of the time and certainly their progeny, whose testimonies could be usefully employed in a more comprehensive (and much needed and timely) research on this most neglected period in the history of the Lithuanian Tatar Muslim community. Such research could potentially build and expand on the work in this article. One can only wish this comes true, and sooner rather than later.

\section{Bibliography}

\section{Archival Material}

Lithuanian Central State Archive, inventory numbers (collection-folder-case-sheet): 391-4-148-2, -2ap, -16.

$84 \quad$ Ibid., 111. 


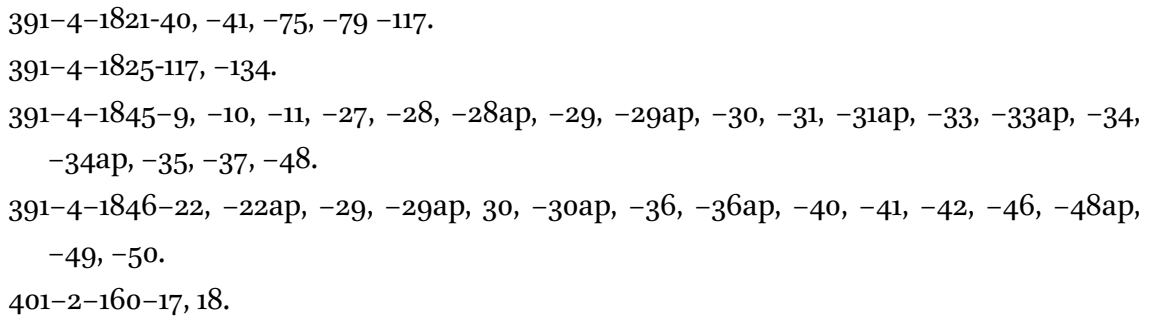
$1622-4-75^{-1,-5,-6 .}$

\section{Literature}

Высочайше утвержденное мнение Государственного Совета 8 января 1851 г. об избрании мулл в магометанских обществах Западньх Губерний [The opinion of the State Council of 8 January $185^{1}$ on the election of the mullahs in Mohammedan communities of the western provinces approved by His Majesty]. http://constitutions. ru/archives/3239, accessed 10 April 2011.

Bairašauskaitè, Tamara. "Musulmonų konfesinė bendruomenė nepriklausomoje Lietuvoje." Lietuvos istorijos metraštis 1991 (1993): 98-114.

- Lietuvos totoriaiXIX amžiuje. Vilnius: Mintis, 1996.

Central Bureau of Statistics. Lietuvos gyventojai: $1923 \mathrm{~m}$. rugsèjo 17 d. surašymo duomenys. Kaunas: Centrinis statistikos biuras, 1925 .

Jakubauskas, Adas, Galimas Sitdykovas, Stanislavas Duminas (eds.). Lietuvos totoriai istorijoje ir kultūroje. Kaunas: Lietuvos totorių bendruomenių sajunga, 2012.

Kolodziejczyk Dariusz. The Crimean Khanate and Poland-Lithuania: International Diplomacy on the European Periphery (15th-18th Century): A Study of Peace Treaties Followed by an Annotated Edition of Relevant Documents. Leiden: Brill, 2011.

Kričinskis, Stanislovas. Lietuvos totoriai [Lithuanian Tatars]. Vilnius: Mokslo ir enciklopedijų leidykla, 1993 .

—. Tatarzy litewscy. Próba monografii historyczno-etnograficznej [Lithuanian Tatars: An attempt at historic-ethnographic monograph]. Warsaw, 1938.

Miskiewicz, Ali. Tatarzy polscy 1918-1939. Zycie spoteczno-kulturalne i religijne. Warsaw: PWN, 1990.

Moslemische Revue. “Eine Neue Moschee zu Kaunas in Litauen.” (Oct. 1933): 91-92.

Šapoka, A. Lietuvos istorija. Kaunas: Book Publishing Commission of the Ministry of Education, 1936.

Senn, Alfred Erich. Lithuania Awakening. Los Angeles: University of California Press, 1990. 